\title{
Negotiating the Roman Past in Later Tenth-century Armenia
}

\section{Tim Greenwood*}

The Byzantine expansion eastwards into historic regions of Armenia in the second half of the tenth century and the Armenian responses to that expansion both receive modest coverage in Armenian historical narratives. Yet several works of Armenian historical literature were composed during this period which do not comment directly upon present circumstances but which, nevertheless, can be examined for what they reveal about the attitudes of their compilers. This study examines how historic Roman-Armenian encounters were represented in three such works. Despite their proximate dating, they attest a range of perspectives. The anonymous author of the History of Taron reimagined the conversion of Armenia at the start of the fourth century by Saint Gregory the Illuminator, highlighting the contribution of the metropolitan of Caesarea in the establishment of sees, monasteries and martyria across the region. A similar process was underway at the time following the Byzantine annexation of Taron and the attendant reconfiguration of the ecclesiological landscape. The History of Uxtanēs bishop of Sebasteia was completed between 980 and 989 CE by an Armenian orthodox bishop and projects historic antagonism between Romans and Armenians. Uxtanēs sharpened the negative presentation of several Roman emperors from Antiquity by applying derogatory epithets usually reserved in Armenian literature for oppressive Persian Šahanšahs. At the same time, Armenian leaders were projected as compromising their autonomy. Uxtanēs also incorporated much-altered traditions about Saint Theodore Tiron and the Forty Martyrs of Sebasteia, implying that they were Armenian Christians persecuted for their faith. Finally, while the Universal History of Step'anos Taronec'i offers an ambiguous portrait of the current Byzantine emperor, Basil II, the writer's antipathy is revealed through his hostile depiction of Constans II whose engagement with Armenia in the middle of the seventh century prefigured that of Basil II in several respects. In all three compositions, the Roman past was used as a mirror to comment upon the Byzantine present.

Keywords: Armenia; Basil II; Byzantium; Constans II; conversion; Saint Gregory; historiography; Sebasteia; Saint Theodore; Tarōn

* Tim Greenwood, Department of Medieval History, University of St Andrews, 71 South Street, St Andrews Fife KY18 9QW, United Kingdom; email: twg3@st-andrews.ac.uk.

I should like to express my thanks to Simon MacLean and Max Diesenberger for their kind invitation to participate and to the anonymous reviewers for their thoughtful comments. Any errors which remain are mine alone. 
The history and literature of tenth-century Armenia has always occupied a liminal position in the field of Armenian studies. From a historiographical perspective, several contentions may be advanced as to why this is the case. In the first place, the tenth century witnessed the progressive, and accelerating, extension of Byzantine power eastwards into the regions and districts of historic Armenia, as Armenian kings and princes conceded their ancestral territories in exchange for lands, status and security within Byzantium. ${ }^{1}$ It was, on the face of it, not an era of national unity, nor heroic resistance in defence of faith, family or patrimony but rather an epoch of compromise and concession. When the study of the Armenian past began in earnest in the nineteenth century, the circumstances of tenth-century Armenia did not support contemporary ambitions for national awakening and self-determination, ambitions which were reflected in terms of political activism and literary output. By way of illustration, one of the central characters in Abovyan's 1841 historical novel Wounds of Armenia. Lament of a Patriot asserts "Give up your life, your spirit, but never give up your native lands to the enemy or live in perpetuity without land «. ${ }^{2}$ Unsurprisingly, it was the earliest Armenian literature, composed in the fifth century CE following the invention of the Armenian script by Mesrop Maštoc', which attracted the greatest scholarly interest. It was generally acknowledged that this was when Movsēs Xorenac'i, termed the father of Armenian literature, had composed his History of Armenia, extending from Creation to the demise of the Arsacid Armenian kingdom in 428 CE. Movsēs' projection of a single kingdom of Armenia, poised between the imperial powers of Rome and Persia yet occupying its own space and seemingly in control of its own destiny, matched contemporary aspirations in ways that the fractured, compromised Armenia presented in the tenth-century compositions did not. Moreover once a hierarchy of medieval Armenian literature had been established, with those associated with Movsēs Xorenac'i at the apex, the contours of subsequent scholarship were set. This hierarchy continues to inform the discipline of Armenian studies today. Whereas Xorenac'i's History has been published and reprinted in several editions and been the focus of over two hundred and fifty dedicated publications, monographs and articles since the middle of the nineteenth century, the late tenth-century History of Uxtanès, has benefited from three editions and received sustained attention in barely a dozen scholarly publications across the same period. ${ }^{3}$

1 Garsoïan, Byzantine annexation, 187-198; Mahé and Mahé, Histoire de l’Arménie, 138-174.

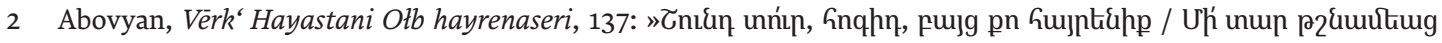

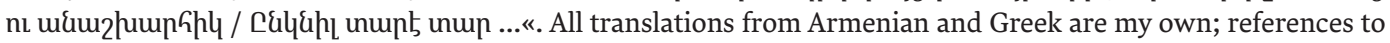
published translations have been supplied should further contextualization be sought. Thomson, Bibliography, 156-167 and 208; Thomson, Supplement, 194-197 and 202. 
Another reason for the lack of interest in tenth-century Armenian history may lie in what might be termed its "narrative deficit«. Although two substantial Armenian historical narratives reflecting on the recent past were assembled at the start of the tenth century by T'ovma Arcruni in 904 CE and Yovhannēs Drasxanakertc'i in 924 CE - and a third by Step'anos Tarōnec'i was completed in 1004/1005 CE, collectively these offer modest coverage of the tenth century as a whole, with the period between 925 and $975 \mathrm{CE}$ obtaining very meagre treatment. ${ }^{4}$ Even the final notices of Step'anos Tarōnec 'i's Universal History are not as substantial from an internal Armenian perspective as might have been anticipated. ${ }^{5}$ They address recent events in Byzantine history - albeit often with an Armenian tinge - in much greater depth than the affairs of Bagratuni, Arcruni or Siwni kings or princes. As a result, anyone wanting to write a conventional narrative history of tenth-century Armenia tracing what happened, to whom and with what result, is confronted with a relative dearth of information. This is compounded by the perennial challenge of how to present the history of a fragmented political landscape, with multiple expressions of "Armenian-ness", in a coherent, meaningful manner. Nor is it possible to offset this narrative deficit by turning to later Armenian compositions. The solitary eleventh-century Armenian history, compiled in the mid-1070s by Aristakēs Lastivertc'i, addresses exclusively eleventh-century affairs, whilst the early twelfth-century Chronicle of Matt'ēos Urihayec'i opens with a fascinating but chronologically muddled account of Armenian history in the second half of the tenth century which was shaped, as Andrews has demonstrated recently, by the prophecies of Yovhannēs Kozern. ${ }^{6}$ His Chronicle provides a twelfth-century vision of tenth-century Armenia, with all the attendant challenges of revision and reimagination that this entails.

Fortunately, however, the discipline of historical enquiry is not limited to narrative reconstruction. Every work of historical literature is an expression of the context in which it was assembled. All historical compositions construct their own stories in their own ways and this is as true within the Armenian tradition as any other. As social, intellectual and cultural productions of knowledge, they attest the attitudes and approaches of the scholars who composed them. This has two consequences for this study. In the first place, there is value in studying the three tenth-century historical narratives in their entirety, for not to do so runs the risk of failing to appreciate to its fullest extent what their authors wanted to communicate. All three reflect universal conceptions of history, starting with the Old Testament figures of Noah (T'ovma and Yovhannēs) or Abraham (Step'anos) and then advancing, each in its own way, through Biblical history and antiquity to the recent past before concluding in the present. Their representations of the remote past do not hold value or significance for the study of that past but they do reveal how their authors utilised it for their own purposes in their own times. Secondly, if we consider the writing of history in tenth-century Armenia - as opposed to the writing of narratives of tenth-century Armenian history - it transpires

4 T'ovma Arcruni, Patmut'iwn tann Arcruneac'; Yovhannēs Drasxanakertc'i, Patmut' 'iwn Hayoc'; Step'anos Tarōnec'i, Patmut 'iwn Tiezerakan. For an introduction to these historical compositions, as well as those discussed below, see Greenwood, Universal History of Step'anos Tarōnec'i, 9-32.

5 Step'anos Tarōnec'i, Patmut'iwn Tiezerakan, 3.22-48, ed. Manukyan, 800-828.

6 Aristakēs, Patmut'iwn Aristakisi Lastivertc'woy; Matt‘ēos Urihayec'i, Žamanakagrut'iwn; Andrews, Matt'ēos Urhayec'i, 30-43. 
that the canon needs be expanded to include at least six other works. Only two of these will be considered in this study but there is merit in listing them here, since not all have been recognized as having a contribution to make to research into tenth and eleventh-century historiography and literature.

These comprise the following: an independent work of Arcruni history, previously, and misleadingly, identified as a continuation of T'ovma's History, composed shortly after $943 \mathrm{CE} ;{ }^{7}$ the History of Ałuank', attributed variously to Movsēs Dasxuranc'i or Movsēs Kałankatuac'i, compiled before $958 \mathrm{CE}$, and focused on Caucasian Albania/Ałuank ${ }^{6}$ in late Antiquity and then the heirs to its political and cultural legacy in eastern Armenia; ${ }^{8}$ a study by a midtenth-century head of the Armenian Church, catholicos Anania Mokac'i, titled Concerning the Rebellion of the House of Atuank" composed in $958 \mathrm{CE}$ which addresses the contemporary political and confessional situation across eastern Armenia; ${ }^{9}$ the History of Tarōn, sometimes attributed to Pseudo-Yovhannēs Mamikonean and also associated with Zenob Glak, composed between $966 / 967$ and 989 CE in two parts, the first focused on the activities of Saint Gregory the Illuminator across the district of Taron, the second largely comprising a series of epic narratives; ${ }^{10}$ the History of Uxtanēs bishop of Sebasteia, compiled between 980 and 989 CE, in three books, the first exploring relations between Romans and Armenians in Antiquity, the second outlining the confessional and ecclesiological conflict between Georgians and Armenians at the start of the seventh century which resulted in schism, and the third, now lost, recording contemporary Armenian engagements with those termed Cad, a pejorative term for Armenians who had changed their minds and accepted the authority and Chalcedonian confession of the Imperial Church; ${ }^{11}$ and the History of the Anonymous Story-Teller attributed to Pseudo-Šapuh Bagratuni, composed between 989 and 1021/1022 CE, divided into two collections of lively, if largely legendary, stories, the first associated broadly with the era of Muhammad and the conquests of the seventh century, the second focused primarily on the deeds of members of the Arcruni, Rsstuni and Anjewac' $i$ families across the districts of eastern Vaspurakan and north-western Iran from the seventh to the later tenth centuries. ${ }^{12}$ Collectively these attest a remarkable vitality and variety to Armenian historical writing in the tenth century.

Two features of this second collection of historical works merit comment. In the first place, they are focused predominantly upon the districts and regions of southern and eastern Armenia rather than the Bagratuni-controlled regions of northern and western Armenia. Even Uxtanēs of Sebasteia can be associated with this broadly southern and eastern orientation. Although he was located in Sebasteia, far to the west, in what had been Roman Armenia in late Antiquity, Uxtanēs was commissioned to compose his History by his teacher Anania Narekac' $i$, the founder of the famous monastery of Narek on the southern shore of Lake Van. ${ }^{13}$

7 T'ovma Arcruni, Patmut'iwn tann Arcruneac', ed. Tër-Vardanean, 264.1-296.29, trans. Thomson, 325-367; Greenwood, Historical tradition, 32-34.

8 Movsēs Dasxuranc'i/Kałankatuac'i, Patmut'iwn Ałuanic.

9 Anania Mokac'i, Yałags apstambut'ean tann Ałuanic'.

10 Yovhannēs Mamikonean, Patmut'iwn Tarōnoy.

11 Uxtanēs, Patmut'iwn Hayoc'. Cad is pronounced Tsad.

12 Anonymous Story-Teller/Pseudo-Šapuh Bagratuni, Patmut 'iwn Ananun.

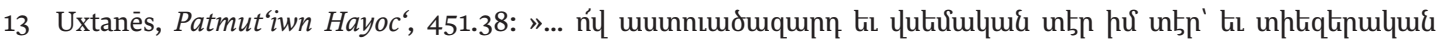

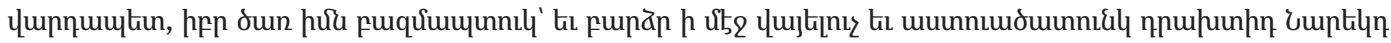
ln々tghtul nıpuun ' ...«. This is contained in the Preface to Book I, which currently lacks a published translation. 
It is difficult to determine whether this broadly southern and eastern focalisation reflects a penchant for historical writing in these regions or is simply a product of the circumstances of survival. Secondly, these works are interconnected, to the extent that the existence of scholarly networks of historical research operating across the southern and eastern regions of Armenia may be posited. The earliest reference to the History of Atuank' occurs in Anania Mokac 'i's study. ${ }^{14}$ The History of History of Tarōn was known to a circumspect Uxtanēs who noted, and rejected, its divergent traditions..$^{15}$ And part II of the History of the Anonymous Story-Teller corresponds in several respects with the History of T'ovma Arcruni, although in this case, an indirect rather than a direct relationship, reflecting a common historical culture, should be envisaged. ${ }^{16}$ In summary, although the narrative deficit for tenth-century Armenian history is unlikely to be closed, there was a wide range of historical literature being composed in tenth-century Armenia which has the potential to provide important insights into contemporary social, intellectual and cultural conditions.

This study analyses how three of the compositions introduced above - the History of Tarōn, the History of Uxtanès of Sebasteia and the Universal History of Step'anos Taronec'i represent aspects of the Roman past, that is to say, the world of Antiquity and late Antiquity in the eastern Mediterranean, down to the era of the Islamic conquests in the middle of the seventh century. It shall be argued that far from reflecting antiquarian interests, each of these broadly contemporaneous compositions - all dating from the four decades between 966/967 and 1004/1005 - exploited the Roman past to comment on present circumstances, when the heir to the Roman empire in the East, Byzantium, began to extend eastwards and impinge on Armenian lordships and communities in a sustained manner for the first time since the start of the eighth century. All three authors were faced with the same challenge, namely how to articulate their opinions on this current Roman resurgence. All three came up with the same solution. They looked back at the interactions between Romans and Armenians recorded in Armenian tradition and adapted them to convey their own views. In effect, the Roman past was used as a window through which to observe and evaluate the Byzantine present. Crucially, whereas the History of Tarōn represented that engagement in positive terms, both Uxtanēs and Step'anos chose to define relations between Armenians and Romans as antagonistic.

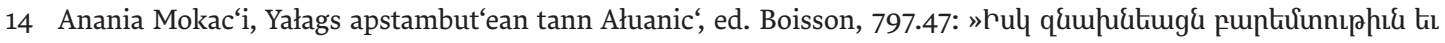

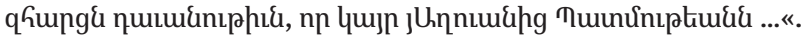

15 Uxtanēs, Patmut'iwn Hayoc', 1.76, ed. Hovannisyan and Madoyan, 509.3-6, trans. Brosset, 275: »Pujg nz

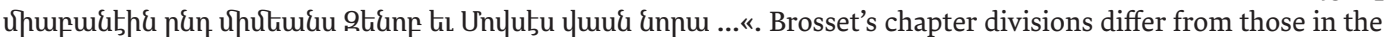
edition; the latter are preferred.

16 Thomson, Anonymous story-teller, 176-181. 


\section{The History of Tarōn}

As Avdoyan demonstrated, a series of features within this composition support the proposition that the History of Tarōn was compiled after the Byzantine annexation of this principality in 966/967 CE and before Uxtanēs completed his own History at some point between 980 and 989 CE. ${ }^{17}$ Yet the work does not consider the tenth century. It is divided into two parts. Part I focuses upon the activities of Saint Gregory the Illuminator in the region of Taron during the conversion of Armenia in the early fourth century, stressing his role in the foundation of the monastery of Glak at Innaknean. Part II comprises a diverse series of narratives, often depicting conflicts involving huge numbers of soldiers (Armenian, Persian and others, but never Roman), situated loosely in the late sixth and early seventh centuries and played out in the immediate vicinity of the monastery of Glak. The history of the monastery, and the efficacy of its miracle-working relics of John the Baptist, provides an overarching thematic unity to Part II. This study, however, will focus on aspects of Saint Gregory's mission to Tarōn recorded in Part I.

Before doing so, it may be helpful to offer a very brief synopsis of this formative moment in the Armenian past. Although the History of Armenia attributed to Agat'angełos is recognised as the standard Armenian account of the conversion narrative, in fact there are multiple accounts of the life and work of Saint Gregory. ${ }^{18}$ Those associated with Agat'angełos divide into two recensions and different versions have been preserved in several languages, including Greek, Arabic, Syriac and Karshuni. Furthermore, there are other accounts, with their own distinctive features, integrated into Armenian historical compositions. This is not the occasion to trace the correspondences and differences between these individual narratives although it is worth noting that much of the research undertaken has focused on defining their differences rather than interpreting or explaining them. The key proposition is that the life of Saint Gregory - including his background and upbringing, his confrontation with King Trdat, his torture and thirteen-year confinement in a pit, the punishment of Trdat, his rescue and preaching, the healing and conversion of Trdat, Gregory's consecration in Caesarea, his missionary journeys, his visit to the emperor Constantine and his final days had a central role in the construction of Armenian communities and identities. In a world characterised by political and ecclesiological division and intense local and regional rivalries, the past was open to endless modification and reinterpretation. Traditions were refashioned to prefigure, and hence legitimise, present circumstances and those from the formative era of Saint Gregory held particular meaning. It is in this context that the account of Saint Gregory's activities in Tarōn projected through the History of Tarön comes sharply in focus.

The following comprises a series of extracts taken from the first letter of Saint Gregory to the metropolitan archbishop of Caesarea in Cappadocia, Łewondèos/Leontius, situated at the beginning of this composition: 
[981] To the one honoured by God and glorified by man, the three-times blessed Têr, the one rendered glorious and holy, Łewondēos, patriarch of that wonderful city, Great Caesarea, on account of your holy ordination upon me [Saint Gregory] ... [982] In particular, we offer a double praise to God, and moreover blessing to you because you generously presented to this land of Armenia the treasure of life, the relics of Saint John the Baptist, the mediator between God and man ... [983] For here, in this land of Armenia, in Armenia IV, at the boundary with Armenia III ... at the place which the Indians and the Persians call Innaknean ... [984] in that same place of Innaknean, I have left two inspired men, Anton and Krōnidēs, whom you out of your love presented to this country of Armenia. These men placed their living bodies on the cross to hang with Christ ... Now according to your customary merciful love which you have for us, I entreat you, give us still further gifts. For the harvest is plentiful but the workers are few. So we ask you [985] that like the workers of our Lord, you shall find other workers for the harvest. One of the workers we request from you is Eliazar, the brother of Zenob whom I consecrated bishop of the Mamikoneans ... And send in particular Timot'ēos, bishop of Agdēn ... ${ }^{19}$

Strikingly therefore, the author of the History of Tarōn did not attempt to relay a full account of Saint Gregory's life and career but chose to begin abruptly part way through. This suggests that the broad outline of the conversion narrative was so well-known no introduction or recapitulation was needed. It also implies that the full narrative was not deemed to be significant or necessary, that the author had a clear purpose for starting at this point. Whereas other versions recall the newly-converted Armenian king Trdat writing to Leontius the metropolitan of Caesarea asking him to ordain Gregory, the History of Tarōn is alone in attesting correspondence between Gregory and Leontius after his episcopal consecration. ${ }^{20}$ Furthermore, whereas Saint Gregory is reported across the versions of Agat'angełos returning to Tarōn from Roman territory accompanied by relics of John the Baptist and the holy martyr of Christ Athenogenes, only the History of Tarōn records the despatch of two clerics, Anton and Krōnidēs, by Leontius in support of Gregory as well as Gregory's request for other trained personnel to assist in the process of conversion. ${ }^{21}$ In his reply, Leontius writes that

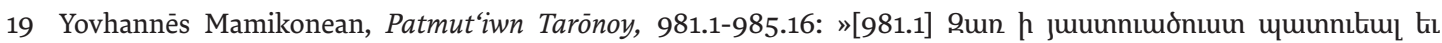

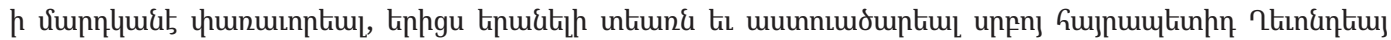

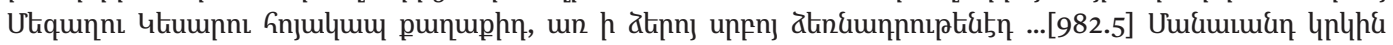

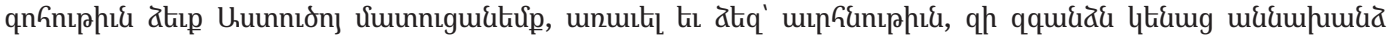

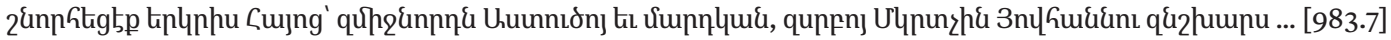

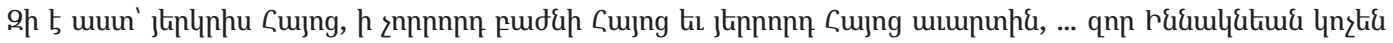

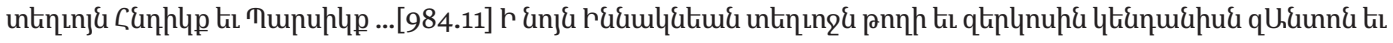

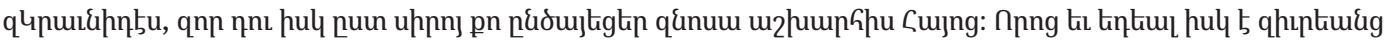

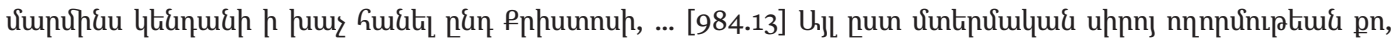

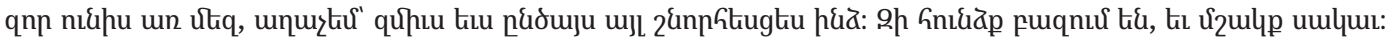

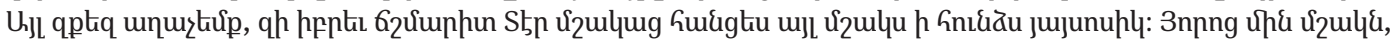

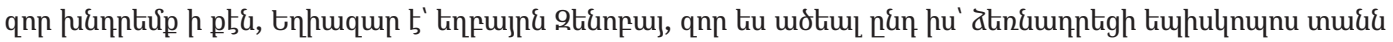

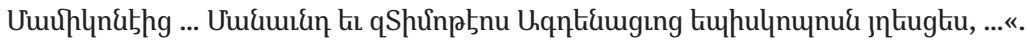

20 Thomson, Lives of Saint Gregory, §§ 794-801, for Trdat's letter; Yovhannēs Mamikonean, Patmut' 'iwn Tarōnoy, 981990, trans. Avdoyan, 55-61, for the exchange between Gregory and Leontius.

21 Thomson, Lives of Saint Gregory, §§ 810-811, for Gregory's return to Tarōn with these relics; Yovhannēs Mamikonean, Patmut'iwn Tarōnoy, 984.11-985.16, trans. Avdoyan, 57-58, for the dispatch of the two named clerics and request for others. 
he has persuaded Epiphanius, a student of Anton, to go to Innaknean with forty ascetics and settle there and then instructs Gregory to appoint Epiphanius as leader of the community. ${ }^{22}$ According to the History of Tarōn, therefore, the personnel for the first monastic community at Innaknean were sent from Roman territory by Leontius. However Leontius then admits to Gregory that he has not been able to find Ełiazar - later identified as bishop of Niwstra - or Bishop Timot'ēos, bishop of Agdēn. ${ }^{23}$ Both had been identified previously by Gregory as suitable for his mission; indeed the latter had been praised for his knowledge of literature. ${ }^{24}$ As a result, Gregory then writes to these bishops directly, observing that he had already appointed Ełiazar's brother, Zenob, as bishop of the places of Innaknean. ${ }^{25}$ Yet in a subsequent passage, Zenob is also titled the abbot of the monastery of Glak. ${ }^{26}$ As outlined below, this fusion of episcopal see and monastery resonates with late tenth-century circumstances.

This is not the first instance of Roman involvement in the life and career of Saint Gregory. Even the standard Armenian version of Agat'angełos' History of Armenia depicts Gregory as a child being brought up in a Christian household in Caesarea in Cappadocia. ${ }^{27}$ His consecration in the same city at the hands of Leontius and the gift of relics also appear in this narrative and many of the other versions. The otherwise unattested correspondence, however, between Leontius and Gregory holds a different importance because it implies an ongoing partnership between the two church leaders, one which is realised through the despatch of named bishops and abbots as well as the forty ascetics. This creates a single geo-ecclesiological landscape stretching from Caesarea to Tarōn through which these figures move without interruption. The singular direction of travel, from Caesarea and the wider Roman world to Taron, reflects the latter's dependency on the metropolitan of Caesarea. It is also striking that the monastery at Innaknean is described as being situated in the Roman province of Armenia IV, at the boundary with Armenia III, "where the Mamikoneans dwell «. ${ }^{28}$ From a spatial perspective therefore, the monastery is imagined as being located within a historic Roman province, highlighting Taron's association with the Roman Empire, downplaying its independent political culture. In sum, the History of Tarōn presents Saint Gregory's relations with Leontius of Caesarea in positive terms, stressing his reliance on Caesarea for ordination, relics and personnel.

Yovhannēs Mamikonean, Patmut'iwn Tarōnoy, 987.13, trans. Avdoyan, 59-60.

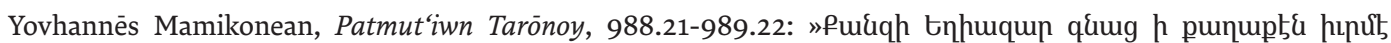

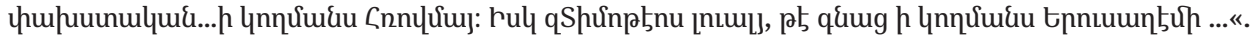

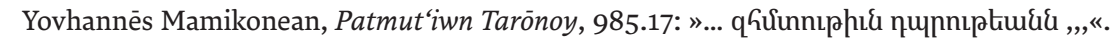

Yovhannēs Mamikonean, Patmut'iwn Tarōnoy, 990.34-992.51, trans. Avdoyan, 61-63.

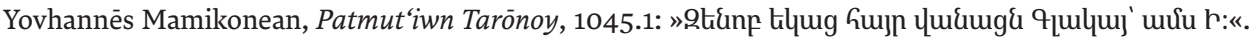

Thomson, Lives of Saint Gregory, §37.

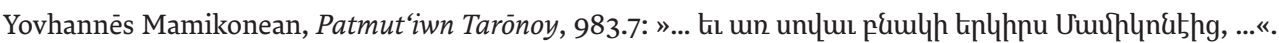


Before addressing the contemporary significance of this relationship, a second dimension of the History of Tarón needs to be stressed. The composition sets out to undermine the primacy of Aštišat, the historic ancient centre of Christian worship and practice in Tarōn, whose church was founded, according to all the narratives associated with Agat'angełos, by Saint Gregory on the site of pagan temples as a martyrium for the relics of John the Baptist and Athenogenes. ${ }^{29}$ Instead it promotes the claims of the monastery of Glak at Innaknean, asserting that Gregory drove the demons away from Innaknean to Aštišat which remained a centre of pagan worship and that it was at Innaknean that Gregory founded a martyrium for the relics of John the Baptist and Athenogenes..$^{30}$ It has been argued recently that such a fundamental shift in the tradition suits the changed conditions operating across the district of Taron after $967 \mathrm{CE}$, when its princes, Gregory and Bagarat, exchanged their patrimonial inheritance for imperial titles and estates further west. ${ }^{31}$ A colophon written in Tarōn in 973/974 $\mathrm{CE}$ confirms that their departure coincided with an episcopal vacancy after the flight and death of Gregory, bishop of the Mamikoneans. It laments that wafter his death, there was much disorder and opposition in connection with the ordination of a bishop «. ${ }^{32}$ At this time of radical political and social restructuring, the monastery of Glak at Innaknean made an audacious bid for authority and sanctity, asserting its prior association with Saint Gregory and with the metropolitan see of Caesarea. The History of Tarōn represents an ambitious and highly creative response to these new circumstances. Remarkably it succeeded. The monastery became one of the most prestigious centres of Armenian spirituality across the centuries, down to its destruction in 1915.

It is only when these two characteristics of the History of Taron - asserting the role of the metropolitan see of Caesarea in supporting the activities of Saint Gregory and promoting the primacy of his foundation at Innaknean over the traditional centre of worship at Aštišat - are studied and treated together that the purposes of the work, and its value for the study of late tenth-century Tarōn, become clear. In normal circumstances, any attempt to subvert centuries-old practices and replace Aštišat with Innaknean would have been inconceivable. Those invested with the ongoing primacy of Aštišat, including, in all likelihood, the bishop, would have been able to overcome any rival by invoking tradition as well as looking for support from members of the lay elite - although hard to prove, it is likely that the majority of Armenian bishops were related to the local princely family. Again, in normal circumstances, the emergence of a rival cultic centre, claiming the legacy of Saint Gregory, would have been met with deep scepticism if not open hostility for daring to challenge longstanding patterns of annual commemoration and popular devotion. In the context of the Byzantine annexation of Tarōn, however, and the disappearance of the lay and clerical elite, new opportunities suddenly presented themselves for the creation of alternative traditions. The monastery of Glak at Innaknean was reimagined as the spiritual centre for the mission of Saint Gregory

29 Thomson, Lives of Saint Gregory, §§809-815. For specific study of this process in Armenia, see Parsamyan, Destruction/sécularisation des temples; and for broad comparison, Emmel, Hahn and Gotter, From Temple to Church.

30 Yovhannēs Mamikonean, Patmut'iwn Tarōnoy, 983.8-984.10, trans. Avdoyan 57.

31 Greenwood, Imagined past, 380.

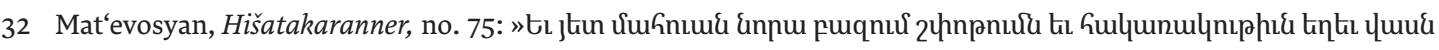

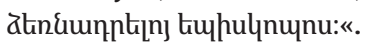


and as a site which enjoyed early and enduring connections with the see of Caesarea. This included the transfer of bishops, abbots and ascetics into Taron, actions which prefigured, and so justified, the contemporary expansion of the Imperial Church eastwards into Tarōn. Few details survive of this process but an outline of the episcopal network dated to the end of the tenth century indicates that Tarōn gained at least four new dioceses, of Tarōn, Mous (the city of Muš), Khatzoun and Khouit (the district of Xoyt'). ${ }^{33}$ The location of Khatzoun is unknown but it is likely to have been associated with an institution dedicated to Surb Xač, Holy Cross. Furthermore, when the Armenian kingdom of Vaspurakan was annexed by Byzantium in $1021 \mathrm{CE}$, six of the new sees established at that time also bore the names of existing religious institutions: Hagios Nikolaos, Theotokos (in Eua, unidentified but conceivably the city of Van) Hagios Nikolaos (in Artzesin/Arčěš, a city on the northern shore of Lake Van), Hagios Georgios, Hagios Elissaios and Theotokos Sedrak. ${ }^{34}$ It appears, therefore, that the correspondence between episcopal see and monastic community imagined in the History of Tarōn was realised in several of the new bishoprics established across Tarōn and Vaspurakan.

In sum, the History of Tarōn portrays the mission of Saint Gregory and institutional developments across Tarōn in ways which, in normal circumstances, would have been unthinkable. With the flight of the lay and clerical elite and the incorporation of Tarōn into the administrative and ecclesiastical hierarchies of the Byzantine empire, however, cherished local traditions were open to appropriation and reinterpretation. The conversion narrative was revised to promote an alternative centre of spirituality and holiness, protected by miracle-working relics and to highlight the contribution of the metropolitan of Caesarea in the establishment of episcopal sees, monasteries and martyria across fourth-century Tarōn. This radical revision of the past, now constructed in terms of Roman-Armenian cooperation and mutuality, served to justify the radical transformation in the ecclesiological landscape underway at the end of the tenth century.

\section{The History of Uxtanès of Sebasteia}

The History of Uxtanēs of Sebasteia projects historic relations between Romans and Armenians in very different terms. It was composed between 980 and 989 CE by Uxtanēs, an Armenian orthodox bishop of Sebasteia, at the request of his teacher, Anania Narekac'i, who was himself responsible for composing an anti-Chalcedonian tract called Hawatarmat or Root of Faith.$^{35}$ Unlike the situation in Taron, where the historic Armenian see of the Mamikoneans had disappeared and been replaced by several new sees of the Imperial Church, the city of Sebasteia seems to have been a site of contemporary ecclesiological confrontation, containing both a Byzantine metropolitan under the jurisdiction of the patriarch of Constantinople and an Armenian bishop under the authority of the Catholicos of the Armenian Church.

33 Notitia 10, 1l. 704-706, 710, ed. Darrouzès, 336: ò toũ Tapúv; tò Moũc; ò Xaţoũv; ò Xovít. Greenwood, Imagined past, 384 .

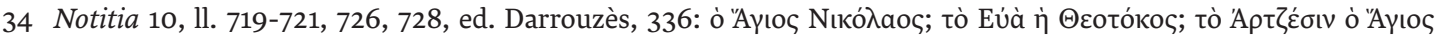

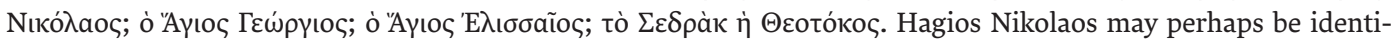
fied with Surb Nikołayos of Apahunik'; see Thierry, Répertoire, no. 391; Hagios Georgios could be any one of five sites: Thierry, Répertoire, no. 489, 525, 555 or 573 or 574. Hagios Elissaios has been identified as Surb Nšan of Č'arahan: Thierry, Répertoire, no. 545; Theotokos/Sedrak has been identified as the monastery of S. Marianos of Sirx: Thierry, Répertoire, no. 575.

35 T'amrazyan, Anania, 130; Uxtanēs, Patmut'iwn Hayoc', 453.53: »... qqhpu Cumuunupưuun ...«. 
Step'anos Tarōnec'i records that in this decade an Armenian bishop of Sebasteia, named Sion, and another Armenian bishop, of Larissa, called Yovhannēs, were induced to switch sides to the Imperial Church while one of the senior Armenian priests in Sebasteia, an old man called Gabriēl, was imprisoned and later died in chains. ${ }^{36}$ Sebasteia had not always been a site of religious tension. The creation of an Armenian diocese seems to have been a recent development, probably in response to the emigration of significant numbers of Armenians seeking employment as soldiers in the Byzantine army. Sebasteia was a major military base and recruitment centre, one that was increasingly important in the second half of the tenth century as Byzantine forces pushed eastwards.

The History of Uxtanēs is divided into three books. The first addresses the distant past from Adam to Saint Gregory's conversion of Trdat at the start of the fourth century; the second records the breakdown in relations between the Armenian and Georgian Churches at the start of the seventh century which ended in a state of permanent schism; and the third describes contemporary relations between Armenians and the Cad, Armenians who had been baptised into the Imperial Church, with its Chalcedonian confession. Although this third book is lost, Uxtanēs included a substantial preface which preserves an impression of what it had comprised, defining those districts, villages, cities and strongholds in "that country" which contained Chalcedonian Armenian (Cad) communities as well as the monasteries and hermits, the bishops and nobles who, at the command of King Smbat, were working alongside him against the fear and brutal threats coming from "that light-faithed people«, by which Uxtanēs meant the Chalcedonian Armenians. ${ }^{37}$ One way of analysing this threebook structure is to interpret it in terms of identity, distinguishing Armenians from Romans in Book I, Armenians from Georgians in Book II and true Armenians from false Armenians, those who had betrayed their anti-Chalcedonian inheritance and sided with the Imperial Church, in Book III. Uxtanēs therefore constructed his understanding of "Armenian « identity in opposition to three other communities represented in Sebasteia at the time - Romans, Georgians and Chalcedonian Armenians. By approaching this work not as a narrative history but as a sophisticated intellectual exercise in defining what it meant to be Armenian from the perspective of an orthodox Armenian cleric in Sebasteia at the end of the tenth century, it obtains a new significance. This study, however, is limited to analysing Roman-Armenian relations as they are presented in Book I.

As Brosset's introduction to his 1871 translation attests, it has long been recognised that Uxtanēs drew extensively upon the first two books of Xorenac'i's History for his account of the distant Armenian past. ${ }^{38}$ Less well-known is that Uxtanēs interleaved this material with extracts from a Roman imperial sequence preserved in a late seventh-century Armenian

36 Step'anos Tarōnec'i, Patmut'iwn Tiezerakan, 3.20, ed. Manukyan, 769-770, trans. Greenwood, 252.

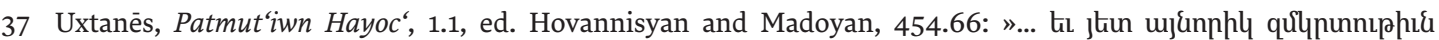

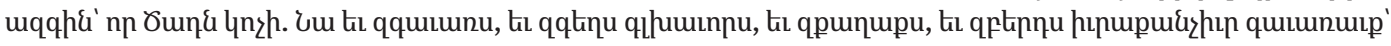

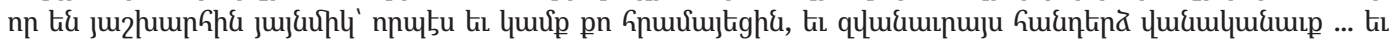

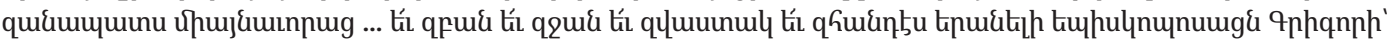

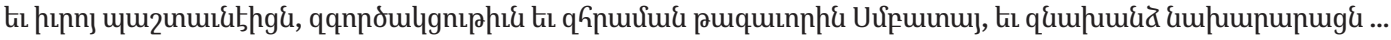

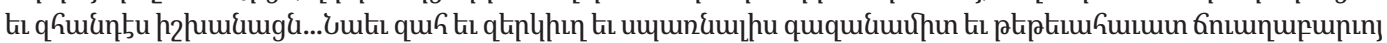

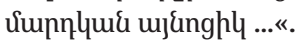

38 Brosset, Deux historiens arméniens, $\mathrm{x}$. 
composition, which, confusingly, goes under several names, including the Chronicle of Anania Širakac'i, the Anonymous Chronicle and the Chronicle of P'ilon Tirakac'i; for the purposes of this study, the last of these will be preferred. ${ }^{39}$ This sequence lists Roman emperors from Julius Caesar to Constantine I, their years in power and key episodes in the history of the early Church - in terms of its leadership, persecution and the emergence and rebuttal of heresies - which took place during their reigns. The list was split into seventeen sections which were then inserted at intervals into the Xorenac' $\mathrm{i}$-based narrative. ${ }^{40}$ The resultant composition is therefore highly fragmented, oscillating between extracts from the two underlying texts. But this process is also instructive because it reveals how Uxtanēs wanted to reimagine the Armenian past. Not only do these short passages of Roman imperial history provide a chronological framework for the past preserved by Xorenac' $i$; they also invite the reader to interpret that past in the context of Roman imperial history and its oppression of the early Church.

Close analysis reveals that Uxtanès did more than simply interleave the extracts from the Chronicle of P'ilon Tirakac'i. He also modified them. When these revisions are assessed collectively, they attest a clear antipathy towards Roman emperors. Uxtanēs sharpened the negative presentation of several emperors by adding derogatory epithets. Nero, Trajan, Severus and Licinius are described as impious, ambarišt $;{ }^{41}$ Maximian and Decius as impious and delighting in evil, ambarišt ew čarap'ar ${ }^{42}$ Aurelian as unjust and impious, anawrēn ew ambarišt; ${ }^{43}$ and Diocletian as idolatrous and impious, krapašt ew ambarišt. ${ }^{44}$ Such epithets are commonly associated in Armenian historical literature with oppressive, persecuting Persian Šahanšahs, not Roman emperors. ${ }^{45}$ Uxtanēs deliberately reshaped these figures, conforming them to the characters of Sasanian rulers and so inviting his audience to understand them as just as oppressive.

Extending this process of comparative textual analysis to the passages derived by Uxtanēs from Xorenac'i's History produces similar results. Episodes from Xorenac'i's History which portrayed interactions between Armenian kings and Roman emperors were selected and also reshaped by Uxtanēs. In a recent study, Nakada has demonstrated that Uxtanēs modified the representation of several Armenian rulers who submitted to Roman authorities. ${ }^{46}$

39 P'ilon Tirakac'i, Žamanakagrut'iwn, 935.1-947.199. This lacks a published translation but for a recent study of this sequence, see Greenwood, New light, 225-229.

40 Uxtanēs, Patmut' 'iwn Hayoc', 1.28, 29, 30, 39, 40, 41, 42, 43, 44, 45, 46, 47, 50, 55, 56, 57 and 59, ed. Hovannisyan and Madoyan, 471.7, 471.15-472.18, 472.14-473.18, 477.7-15, 478.25-34, 479.13-17, 480.11-19, 481.16-482.26, 482.6-483.16, 483.8-15, 484.8-9, 484.17-27, 487.7-20, 489.6-490.17, 490.12-491.21, 492.23-31 and 494.1-8, trans. Brosset, 227-229, 236-239, 241-245, 247, 250-251, 253-255, 257 and 259-260.

41 Uxtanēs, Patmut' 'iwn Hayoc', 1.40, 42, 44 and 61, ed. Hovannisyan and Madoyan, 478.29., 480.13, 482.7 and 495.2, »uúpunh2u«", trans. Brosset 238, 241, 243 and 260.

42 Uxtanēs, Patmut'iwn Hayoc', 1.46 and 50, ed. Hovannisyan and Madoyan, 484.9 and 487.7, "uúpuphru til ¿wipuuum «, trans. Brosset 245 and 250.

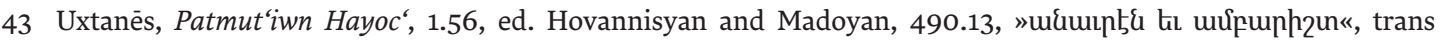
Brosset, 255.

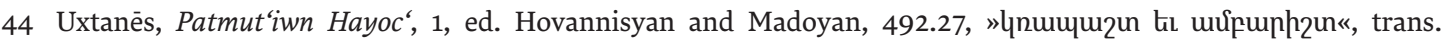
Brosset, 257.

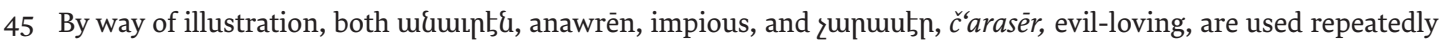
of the Persian king and Persians generally in Ełišě's History.

46 Nakada, Uxtanēs, $177-181$ and 189. 
Whereas Xorenac'i maintained that the Armenian king Aršam negotiated a peace treaty with the Romans because he was unable to obtain any assistance from Persia, and that under its terms he gave tribute for Mesopotamia and Caesarea, Uxtanēs omitted these mitigating comments about Persia, stating simply that in Aršam's time, Armenia began to pay tribute to the Romans. ${ }^{47}$ The qualification that the tribute was due from only certain territories was also dropped, implying that it was levied across the whole of Armenia. According to Xorenac' $i$, "King Eruand gave support to the Romans and was completely untroubled in the reigns of Vespasian and Titus, granting them Mesopotamia «;4 for Uxtanēs, »Eruand gave support to the Roman emperors Vespasian and Titus, granting them Mesopotamia ${ }^{49}{ }^{49}$ This subtle change creates the impression that Eruand had submitted to the Roman Empire, not that he had retained his status as an independent monarch. These alterations may appear to be minor but they serve to generate a straightforward narrative, of Armenian submission and Roman annexation, with the nuances and qualifications supplied by Xorenac'i removed. Arguably Uxtanēs revised this past to comment on his contemporary circumstances, involving an assertive, expanding Byzantium and Armenian compromises and concessions. In this respect the retention of Mesopotamia in his notice concerning Eruand may have been deliberate. Mesopotamia had an entirely different tenth-century meaning to its Antique definition, being the name of a Byzantine theme (military province) located south-east of the theme of Sebasteia. ${ }^{50}$

Although Uxtanēs derived much of the content of Book I from Xorenac'i's History and the Chronicle of P'ilon Tirakac'i, he also drew upon other materials. Two passages of hagiographical origin stand out. The first comprises a short account of the life and martyrdom of Saint Theodore Tiron, the Recruit, sometimes also known as Saint Theodore of Amaseia; the second consists of a longer narrative describing the circumstances in which the Forty Martyrs of Sebasteia went to their deaths. ${ }^{51}$ Both cults were prominent in the eastern Mediterranean from the late fourth century and continued to be very popular in the late tenth century, especially among soldiers..$^{52}$ The traditions preserved by Uxtanēs, however, are not well-studied and await comparative evaluation with the versions preserved in Greek and Armenian. ${ }^{53}$ Nevertheless, for our purposes, two particular features merit comment.

47 Movsēs Xorenac'i, Patmut'iwn Hayoc', 2.24, ed. Abełean and Yarut'iwnean, 139.4-10, trans. Thomson, 157-158; Uxtanēs, Patmut'iwn Hayoc', 1.30, ed. Hovannisyan and Madoyan, 472.9-10, trans. Brosset, 229.

48 Movsēs Xorenac'i, Patmut'iwn Hayoc', 2.38, ed. Abełean and Yarut'iwnean, 164.9-12: "Puujg phlynıuu unditjnu

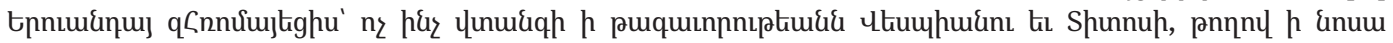
quhquqtinu .....

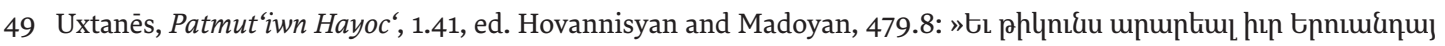

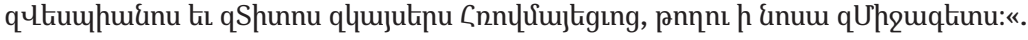

50 Oikonomidès, Les Listes, 349, 354; Nakada, Uxtanēs, 171-173. The theme of Mesopotamia is first attested under Leo VI in 899/901. Sebasteia was a theme by 911. Mesopotamia became a katepanate in 976 with its own doux.

51 Uxtanēs, Patmut'iwn Hayoc', 1.46 and 1.61 respectively; Greenwood, Universal History, 28-30; Nakada, Uxtanēs, 182-188.

52 Walter, Warrior Saints, 44-66 (St Theodore Tiron and St Theodore Stratelates) and 170-177 (St Jyion and the XL Martyrs of Sebasteia).

53 Haldon, Tale of Two Saints; Karlin-Hayter, Passio of the XL. 
In the first place, it is striking that Saint Theodore is described as coming "from the village of Sabobē, six miles from the city of Berissa, in the district of Armeniakon which was called Second Armenia «. ${ }^{54}$ In other words, Saint Theodore was represented as being an Armenian, born within fifty miles of Sebasteia. This origin is otherwise unattested. Uxtanēs does not specify the origins of the Forty Martyrs but his account also permits an "Armenian « interpretation. According to Uxtanēs, the emperor Licinus sent a centurion with soldiers to compel the faithful »in the district of Cappadocia and the theme of $\left\{\mathrm{T}^{\prime} \mathrm{ew}\right\}$ Laxunēk' (Lykandos?) and Anatolikon and Charsianon and Armeniakon and Dazimon « to worship idols or to suffer a cruel death. ${ }^{55}$ These unspecified faithful fled to the borders of the territory of Sebasteia and took refuge in remote places, implying that they had been living in and around Sebasteia. For Uxtanēs, the Forty Martyrs were soldiers who refused to obey Licinius' command to persecute the faithful, not soldiers who had refused to obey Licinius' command to worship idols. One interpretation of this revision is that it enabled orthodox Armenian Christians to identify with the persecuted "faithful«. Uxtanēs states that the site of the subsequent massacre of the "faithful« was called Ekełeac'ajor, in Armenian the "Valley of Churches", implying that they were indeed Armenian. He then describes how the Forty fled to a cave on the bank of the river Halys, a stronghold at that time which "now « was a settlement called K'aj Vahan, an unequivocally Armenian name, Vahan the Brave, where the saints were still venerated. ${ }^{5}$ Again the Armenian identity of the Forty is implied. Nakada has also proposed that this feature of the much-altered tradition may have been intended for orthodox Armenian soldiers serving Byzantine commanders, inspiring them to act as their forebears had done in remaining loyal to orthodox Armenian tradition. ${ }^{57}$

Secondly, both passages support the hostile projection of Roman imperial authority across the composition. Saint Theodore is martyred in Amaseia during the reign of the impious and delighting-in-evil Maximian. The Forty Martyrs on the other hand, are martyred in Sebasteia on the orders of the impious Licinius. When the emperor learned of their disobedience, he ordered the doux and judge of Sebasteia, to locate the Forty, seize them and take them back to Sebasteia to be tortured and either submit to his orders to worship idols or die of their wounds. ${ }^{58}$ Two features of this narrative stand out. The use of the qualifying impious, ambarišt, for Licinius confirms that it was Uxtanēs who inserted these derogatory epithets because this passage was extracted from a separate source. And secondly, the Roman representatives in Sebasteia were identified using titles which date from the second half of the tenth century, not the first decades of the fourth century. In using doux and judge, Uxtanès was implying that the current office holders in Sebasteia were representatives of an impious emperor. This confirms his antipathy for Byzantium.

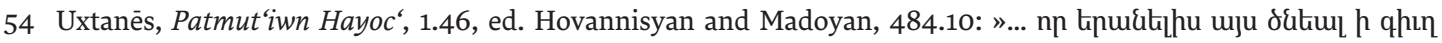

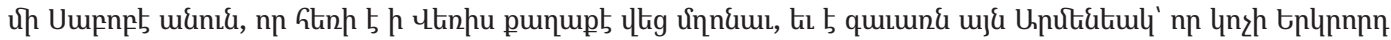
Cuup:«; trans. Brosset, 245-246. It is likely that gawar, district, here stands for theme.

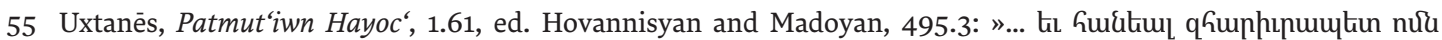

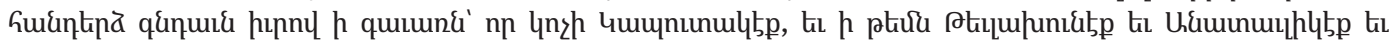

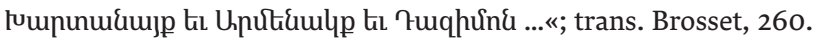

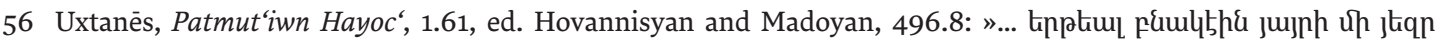

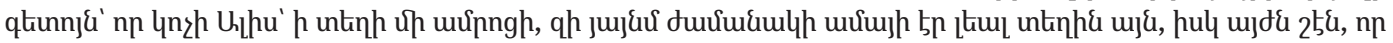
पn々h Puq-umfuiqu] ...«; trans. Brosset, 261.

57 Nakada, Uxtanēs, 185-186.

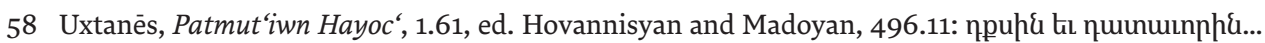


In sum, Book I's commentary on historic relations between Romans and Armenians can be interpreted as a sophisticated commentary on the current circumstances in and around Sebasteia which saw Armenians both accepting and rejecting inclusion within the Imperial Church. It is striking that Uxtanēs criticises both Roman and Armenian rulers. Roman emperors are projected as impious persecutors who presided over ecclesiastical disorder and tumult but Armenian kings do not escape sanction, represented as being liable to compromise their autonomy and submit to the Romans. Uxtanēs was writing at a time when just such a practice was happening. The princes of Tarōn had recently exchanged their ancestral territories for status and territories further west while the current Arcruni kings of Vaspurakan had shown their sympathies through their participation in the translation of a fragment of the True Cross sent by Basil II in 983 CE. Uxtanēs composed Book I in the knowledge of, and in opposition to, events such as these. Through the creative reimagination of the lives of Saint Theodore, the Forty Martyrs of Sebasteia and the unspecified »faithful«, Uxtanēs claimed them as Armenians whose defiance in the face of Roman persecution, even to death, was worthy of commemoration and, by implication, emulation. It is unclear how influential Uxtanēs' History was, nor the extent to which it reflected local sentiment. The subsequent history of the Armenian orthodox see of Sebasteia is obscure, to the extent that we do not know if Uxtanēs had any successors, nor if an Armenian orthodox community persisted for any length of time.

\section{The Universal History of Step'anos Tarōnec ‘ $i$}

Unlike the previous two historical compositions, the Universal History is not confined to the distant past but covers the whole of human history from Creation down to the year 1004/1005 CE. It too is divided into three books. Book I extends from Creation to the accession of King Trdat at the turn of the fourth century; Book II covers the period from Trdat and Saint Gregory down to the restoration of an Armenian kingdom under Ašot I Bagratuni in 884 CE; Book III records events from then until the present. It therefore comments on both the remote Roman past and the present Byzantine resurgence. Scholars, however, have tended to focus on the coverage of tenth-century affairs found in Book III and to ignore the first two books beyond occasional snippets of otherwise unattested information. This study argues for a different approach, stressing the limitations of Book III and the historical potential of Books I and II.

Even a cursory examination of Book III confirms that Step'anos was living through an era of confessional tension. He himself was a member of the orthodox Armenian Church and there can be no doubt that his commitment to this institution, its traditions and teachings shaped his composition. His comments on the oppression of the Armenian orthodox in Sebasteia have been highlighted previously but it is also relevant to note that he chose to include a long and learned defence of Armenian orthodoxy addressed to the metropolitan of Sebasteia, in the course of which the metropolitan is chastised for his stupidity, error, blasphemy and ignorance. ${ }^{59}$ Furthermore Step'anos followed this rhetorical and theological tour de force with a notice recording the grisly fate of the metropolitan at the hands of the Bulgars, accused of duplicity in a diplomatic incident, condemned as a dog and burned alive. ${ }^{60}$ His antipathy towards the Imperial Church is incontrovertible.

59 Step'anos Tarōnec'i, Patmut'iwn Tiezerakan, 3.21, ed. Manukyan, 770.1-800.233, trans. Greenwood, 253-283. 60 Step'anos Tarōnec'i, Patmut'iwn Tiezerakan, 3.22, ed. Manukyan, 80o.1-5, trans. Greenwood, 283-284. 
His attitude towards the Byzantine state, however, is harder to discern. While Basil II is not openly criticised, nor is he eulogised, lending credence to the view that Step'anos adopted a judicious ambiguity when portraying the current emperor. ${ }^{61}$ Yet it is striking to observe how many of the extracts associated with Basil II record challenges to his authority, whether in terms of civil war, military defeat or natural disaster. Furthermore, one of Basil II's principal rivals, Bardas Skleros, is defined unequivocally as king in three chapters and praised for being "a valiant man and an expert in warfare ${ }^{62}{ }^{6}$ From this, one might infer that Step'anos was unfavourably disposed towards Basil II but his overall presentation amounts to a subtle critique which leaves space for alternative interpretations. Admittedly, his depiction of previous tenth-century emperors does not provide much assistance; these figures obtain very brief coverage indeed. If, however, we move further back in the narrative, to the seventh century, we obtain a much clearer impression of Step'anos Tarōnec'i's own attitude towards Byzantine imperial authority.

Book II chapter 2 outlines the actions of the emperor Constans II in relation to Armenia during the era of the Arab conquests and the circumstances in which a long letter to the emperor defending the Armenian confessional position was drafted. ${ }^{63}$ Both the narrative and the long extract from the letter were derived from the History attributed to Sebeos, a work compiled in the middle of the seventh century. While the extract from the letter was copied without redaction or amendment, suggesting that it held particular value for Step'anos, the accompanying narrative was adjusted in several ways. It opens with a notice on the decision of T'èodoros Ŕštuni, titled the commander of Armenia and previously the principal Armenian client of Constans II, to abandon the emperor and submit to the Arabs. ${ }^{64}$ Sebeos interpreted his betrayal in hostile terms, describing it as "a pact with death and an alliance with hell ${ }^{65}{ }^{65}$ Step'anos however recasts it as a pragmatic response to the Arab conquest and reports it in neutral terms. The emperor Constans II is described by Step'anos as responding to this treachery by advancing into Armenia in great anger, boasting that he would purge it thoroughly $;{ }^{66}$ this emotional response is not found in Sebeos' original. According to Step'anos, the Catholicos Nersēs III went out to meet Constans and sought to bring about a reconciliation. On arriving in the city of Dvin, Constans ordered that Roman priests should celebrate the sacrament in the churches. ${ }^{67}$ These details broadly align with Sebeeos' account. However the contentions that many were offended when the emperor and Nersēs took communion

61 Basil II first appears in 3.10 and features prominently thereafter.

62 Bardas Skleros is called king, puqquinn£ uupn, in 3.14, 15 and 20. Step'anos Tarōnec'i, Patmut'iwn Tiezerakan, 3.14, ed. Manukyan, 762.1: "... np th uup puq tı lnpnuh h qnnd uquuntpuquiug:«; trans. Greenwood, 242.

63 Step'anos Tarōnec'i, Patmut‘iwn Tiezerakan, 2.2, ed. Manukyan, 694.97-701.149, trans. Greenwood, $157-163$.

64 Step‘anos Tarōnec'i, Patmut‘iwn Tiezerakan, 2.2, ed. Manukyan, 694.98: "9np unkukul uuu 하nnnnnup

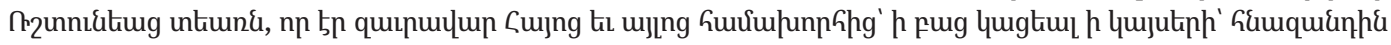
Suflyug:«.

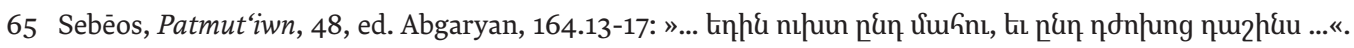

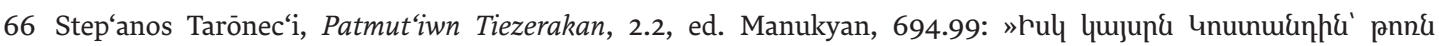

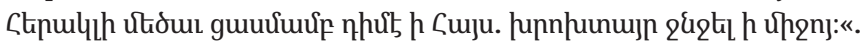

67 Step'anos Tarōnec'i, Patmut'iwn Tiezerakan, 2.2, ed. Manukyan, 694.100, trans. Greenwood, $157-158$. 
together, and that the nobility were treated with contempt on that occasion, are both reactions inserted by Step'anos. ${ }^{68}$ Finally, and perhaps most tellingly, the Catholicos Nersēs III is presented by Step'anos as pious, Christ-loving, and truth-relating, leading the Armenian faithful in their opposition to Constans II and Chalcedonian doctrine. ${ }^{69}$ In the History attributed to Sebēos, however, Nersēs is described as keeping the bitter poison of Chalcedon in his heart, of perverting the true faith of Saint Gregory, and muddying the pure waters of Armenian orthodoxy. ${ }^{70}$ In other words, Step'anos has inverted the portrait of Nersēs III to present him as a firm advocate of traditional Armenian orthodoxy. At the same time, he substantially revised the figure of Constans II, now an angry emperor determined to enforce Chalcedon on a defiant Armenia.

Why did Step'anos select such a passage for inclusion in his Universal History and why did he adapt it in the ways outlined? Although incapable of proof, it seems most likely that he did so because he interpreted the circumstances as analogous to his own time. He was confronted with a resurgent Byzantium and an expanding Imperial Church. Basil II had travelled through the districts of Armenia in the year 1000, meeting members of the elite including Abas Bagratuni, the king of Vanand based in Kars, and Senek'erim Arcruni, king of Vaspurakan. ${ }^{71}$ They had been rewarded with unspecified royal honours, horses and mules, splendid clothing and much gold. Rather than criticising these actions, Step'anos looked back to an earlier era, when a Roman emperor had travelled to Armenia and had met with Armenian princes and bishops. He reshaped the narrative of this earlier engagement to create the story he wanted to tell, of Byzantine pressure to convert and Armenian defiance. In this respect, two additional sentences inserted by Step'anos are particularly revealing. The first - purportedly in an edict composed by Constans II and the patriarch of Constantinople and sent to the Catholicos Nersēs III, all the bishops and the great T'ēodoros Řštuni - warns that "if anyone from the princes should be found who resisted the command [to accept Chalcedon], he was to be removed from the honour and office of prince and all of his possessions were to be seized for the royal treasury and he was to be conveyed to the court of kings, there to make reply «. ${ }^{72}$ Step'anos therefore imagined recalcitrant Armenian princes losing their noble status and their territories to the imperial treasury. This can be viewed as an interpretation of what was happening at the end of the tenth century, when members of the Armenian elite were yielding their ancestral domains to Byzantium. For Step'anos, it was the result of imperial pressure to accept Chalcedon. I suspect that for many members of the Armenian elite, the benefits of territory, status and security within the Byzantine Empire outweighed

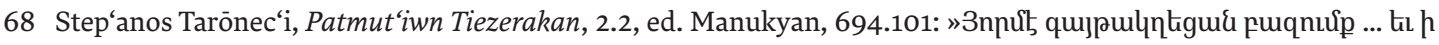

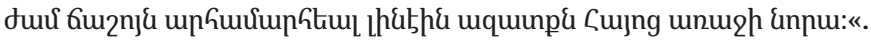

69 Step'anos Tarōnec'i, Patmut'iwn Tiezerakan, 2.2, ed. Manukyan, 695.106, 696.108: »...un unpuubp lupnnhlpnuर

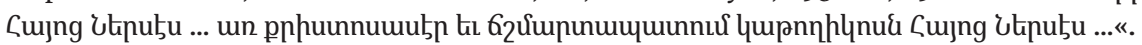

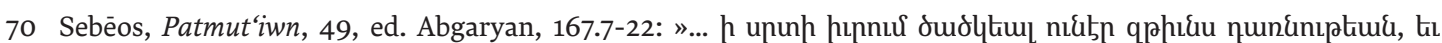

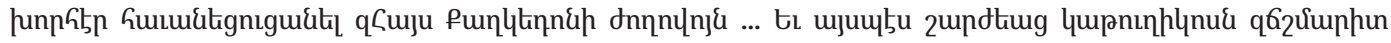

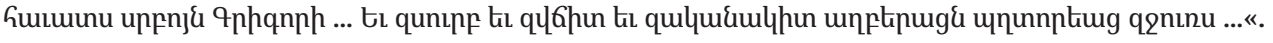

71 Step'anos Tarōnec'i, Patmut'iwn Tiezerakan, 3.43, ed. Manukyan, 822.6-824.23, trans. Greenwood, 308-310.

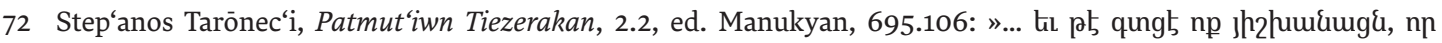

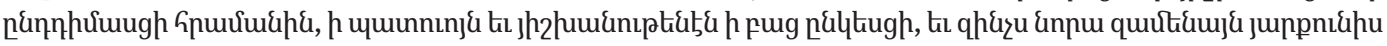

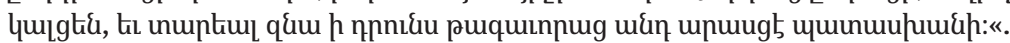


any qualms they might have had over abandoning confessional allegiances - exactly the situation that Uxtanēs was so keen to resist. The second sentence confirms this. It records the response of Nersēs, T'èodoros and all the bishops and princes of the country: "It would be better for us to die than to exchange the doctrine of Saint Gregory for that of the Council of Chalcedon and the Tome of Leo ${ }^{73}{ }^{73}$ For Step'anos, his sponsor Catholicos Sargis I Sewanc ' $\mathrm{i}$ and other members of the Armenian orthodox Church, this is what was at stake at the end of the tenth century.

\section{Conclusion}

The second half of the tenth century witnessed an extension of Byzantine hegemony whether viewed in political, administrative, ecclesiological or cultural terms - across a swathe of Armenian districts and lordships. This Roman resurgence generated a surprisingly rich and varied collection of Armenian historical compositions. The compilers of these works used the past to speak about the present, incorporating and adapting earlier accounts of encounters between Romans and Armenians. Existing narratives could be reshaped to support very different positions. Whereas the History of Taron emphasized the cooperation of the see of Caesarea - and by extension the Imperial Church - in the creation of ecclesiastical and monastic institutions in early fourth-century Tarōn, the histories of Uxtanēs and Step'anos Tarōnec'i both projected historic antagonism between Romans and Armenians. Although Step'anos covered the recent past and even current affairs in his Universal History, his own attitude towards Byzantine imperial authority can be seen most clearly in his refashioned description of the encounter between Constans II and Nersēs III. We are never going to be in a position to determine whether this creative reimagination of the past was a matter of preference or necessity. On the one hand, writing about the recent past or the present was fraught with danger. In the fragile and fluid context of late tenth-century Armenia, one could never be confident about the future. Who could predict which members of the lay or clerical elite would be tempted to turn Byzantine? This was a matter of deep concern for orthodox Armenian clerics but we should recognize that it may not have been so for those who embraced the opportunity to settle in and serve Byzantium, even if their voices are hard to discern in the written record. But we should perhaps acknowledge that practical considerations may also have had a part to play in recycling the past, that Armenian scholars may not all have been able to acquire sufficient knowledge to compose a narrative dealing with contemporary affairs. In such circumstances, reshaping the historical works available to them may have been the most straightforward, perhaps even the only, option when it came to the writing of history. Negotiating the Roman present invited, and may even have demanded, engagement with the Roman past.

73 Step'anos Tarōnec'i, Patmut'iwn Tiezerakan, 2.2, ed. Manukyan, 696.111: „Luu uhgh utiq utinukitl, puid pt

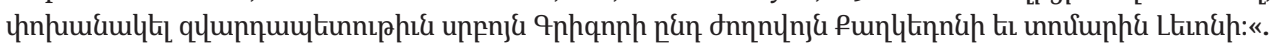




\title{
References
}

\author{
Abbreviations \\ MH Matenagirk' Hayoc \\ OPP Occasional Papers and Proceedings \\ REArm Revue des études arméniennes
}

Abovyan, Xač'atur, Vèrk' Hayastani Ołb hayrenaseri (Tifliz, 1858). Accessed on 27 July 2019 at HathiTrust Digital Library: babel.hathitrust.org/cgi/pt?id=mdp.39015041468003\&view $=1$ up\&seq $=149$.

Anania Mokac'i, Tearn Ananiayi Hayoc' kat'ołikosi yałags apstambut'ean tann Ałuanic' or ĕnd žamanaks leal ic'ē jernadrut'iwnn artak'oy surb lusaworč‘i at'oroyn, ed. Azat Bōzoyean, MH 10 (Ant'ilias, 2009) 255-274; repr., with facing French translation: Patricia Boisson, Du seigneur Anania Catholicos d'Arménie. Au sujet de la rébellion de la maison des Ałuank qui a été consacrée quelquefois hors du siège du saint Illuminateur, Mélanges Jean-Pierre Mahé, Travaux et Mémoires 18 (2014) 786-829.

Andrews, Tara L., Matt'éos Urihayec 'i and His Chronicle (Leiden, 2017).

Anonymous Story-Teller/Pseudo-Šapuh Bagratuni, Istorija anonimnogo povestvovatelja: psevdo-Shapukh Bagratuni/Patmut'iwn Ananun zruc'agri karcec'eal Šapuh Bagratuni, ed. with parallel Russian translation Margo O. Darbinyan-Melik'yan (Erevan, 1971); English translation: Robert W. Thomson, The anonymous story-teller (Also known as "PseudoŠapuh«), REArm 21 (1988-1989) 171-232.

Aristakēs, Patmut 'iwn Aristakisi Lastivertc'woy, ed. Karēn N. Yuzbašyan (Erevan, 1963). French translation: Marius Canard and Haïg Berbérian, Aristakès de Lastivert. Récit des malheurs de la nation arménienne, Bibliothèque de Byzantion 5 (Brussels, 1973).

Emmel, Stephen, Johannes Hahn and Ulrich Gotter (eds.), From Temple to Church. Destruction and Renewal of Local Cultic Topography in Late Antiquity (Leiden, 2008).

Garsoïan, Nina G., The Byzantine annexation of the Armenian Kingdoms in the eleventh century, in: Richard G. Hovannisian (ed.), The Armenian People From Ancient to Modern Times, vol. 1 (New York, 1997) 187-198.

Greenwood, Tim, Historical tradition, memory and law in Vaspurakan in the era of Gagik Arcruni, in: Zaroui Pogossian and Edda Vardanyan (eds.), The Church of the Holy Cross at Attamar. Politics, Art, Spirituality in the Kingdom of Vaspurakan (Leiden, 2019) 27-48.

Greenwood, Tim, "Imagined past, revealed present". A reassessment of Patmut 'iwn Tarōnoy [History of Tarōn], Mélanges Jean-Pierre Mahé, Travaux et Mémoires 18 (2014) 377-392.

Greenwood, Tim, "New light from the East«. Chronography and ecclesiastical history through a late seventh-century Armenian source, Journal of Early Christian Studies 16/2 (2008) 197-254.

Haldon, John, A Tale of Two Saints. The Martyrdoms and Miracles of Saints Theodore sthe Recruits and the General, Translated Texts for Byzantinists 2 (Liverpool, 2016).

Karlin-Hayter, Patricia, Passio of the XL martyrs of Sebasteia. The Greek Tradition: the earliest account, Analecta Bollandiana 109 (1991) 249-304.

Mahé, Annie, and Jean-Pierre Mahé, Histoire de l'Arménie des origines à nos jours (Paris, 2012). Mat'evosyan, Artašēs S., Hayeren Jeragreri Hišatakaranner 5-12 dd (Erevan, 1988). 
Matt'ēos Urhayec'i, Žamanakagrut'iwn, ed. Mambrē Melik'-Adamean and Nersēs TērMik'ayēlean (Vałaršapat, 1898; repr. with parallel modern Armenian translation by Hrač Bart'ikyan, Erevan, 1991). English translation: Ara Dostourian, Armenia and the Crusades, 10th to 12th centuries. The Chronicle of Matthew of Edessa (Lanham, MD, 1993).

Movsēs Dasxuranc'i/Kałankatuac'i, Patmut' iwn Ałuanic 'Ašxarhi, ed. Varag Arak'elyan (Erevan, 1983). English translation: Charles J. F. Dowsett, The History of the Caucasian Albanians (London, 1961).

Movsēs Xorenac'i, Patmut'iwn Hayoc', ed. Manuk Abełean and Sēt' Yarut'iwnean (Tiflis, 1913; repr. Delmar, NY, 1981; rev. edn. (with collations by A. B. Sargsean) Erevan, 1991; repr. in MH 2, Ant'ilias, 2003, 1737-2121); English translation: Robert W. Thomson, Moses Khorenats 'i. History of the Armenians, Harvard Armenian Texts and Studies 4 (Cambridge, Mass., 1978); revised edition (Ann Arbor, MI, 2006).

Nakada, Kosuke, Uxtanēs of Sebasteia and Byzantine-Armenian relations in the tenth century, REArm 38 (2018-2019) 167-194.

Notitiae episcopatuum Ecclesiae Constantinopolitanae, ed. Jean Darrouzès (Paris, 1981).

Oikonomidès, Nicolas, Les Listes de préséance byzantines des IXe et Xe siècles (Paris, 1972).

Parsamyan, Arevik, Destruction/sécularisation des temples et premières implantations d'églises en Arménie d'après les données archéologiques, in: Pascal-Grégoire Delage (ed.), Saint Grégoire l'Illuminateur ou les commencements de l'Eglise d'Arménie (Royan, 2016) 23-59.

P'ilon Tirakac'i, Žamanakagrut'iwn, ed. Alek'san Hakobyan, MH 5 (Ant'ilias, 2005) 899-969. Thomson, Robert W., A Bibliography of Classical Armenian Literature to 1500 AD (Turnhout, 1995).

Thomson, Robert W, Supplement to A Bibliography of Classical Armenian Literature to 1500 $A D$, Le Muséon 120 1/2 (2007) 163-223.

Sebēos, Patmut'iwn Sebēosi, ed. Gevorg V. Abgaryan (Erevan, 1979); repr. in MH 4, (Ant'ilias, 2005) 449-565; English trans. and comm., Robert W. Thomson and James D. HowardJohnston, The History Attributed to Sebeos, 2 vols., Translated Texts for Historians 31 (Liverpool, 1999).

Step'anos Tarōnec'i, Patmut'iwn Tiezerakan, ed. Gurgēn Manukyan, MH 15 (Ant'ilias, 2012) 617-829. English translation: Tim Greenwood, The Universal History of Step'anos Taronec'i (Oxford, 2017).

T'amrazyan, Hrač'ya H., Anania Narekac'i kyank'é ev matenagrut'yunĕ (Erevan, 1986).

Thierry, Michel, Répertoire des monastères arméniens (Turnhout, 1993).

T'ovma Arcruni, Patmut'iwn tann Arcruneac', ed. Gēorg Tēr-Vardanean, MH 11 (Ant'ilias, 2010) 13-313. English translation: Robert W. Thomson, History of the House of the Arcrunik' (Detroit, MI, 1985).

Uxtanēs, Patmut'iwn Hayoc', ed. Petros Hovannisyan and Gēorg Madoyan, MH 15 (Ant'ilias, 2012) 439-616. French translation: Marie-Félicité Brosset, Deux historiens arméniens. Kiracos de Gantzac, XIIIe S., Histoire d'Arménie, Oukhtanès d'Ourha, Xe S., Histoire en trois parties (St Petersburg, 1870) 206-351; partial English translation: Zaven Arzoumanian, Bishop Ukhtanes of Sebastia, History of Armenia Part II, History of the Severance of the Georgians from the Armenians (Fort Lauderdale, FLA, 1985).

Walter, Christopher, The Warrior Saints in Byzantine Art and Tradition (Aldershot, 2003).

Yovhannēs Drasxanakertc'i, Patmut'iwn Hayoc', ed. Gēorg Tēr-Vardanean, MH 11 (Ant'ilias, 2010) 315-628. English translation: Krikor H. Maksoudian, Yovhannès Drasxanakertc $i$. History of Armenia, OPP 3 (Atlanta, GA, 1987). 
Yovhannēs Mamikonean, Patmut'iwn Tarōnoy, ed. Alek'san Hakobyan, MH 5 (Ant'ilias, 2005) 971-1126; English translation: Levon Avdoyan, Pseudo-Yovhannēs Mamikonean. The History of Tarōn, OPP 6 (Atlanta, GA, 1991). 